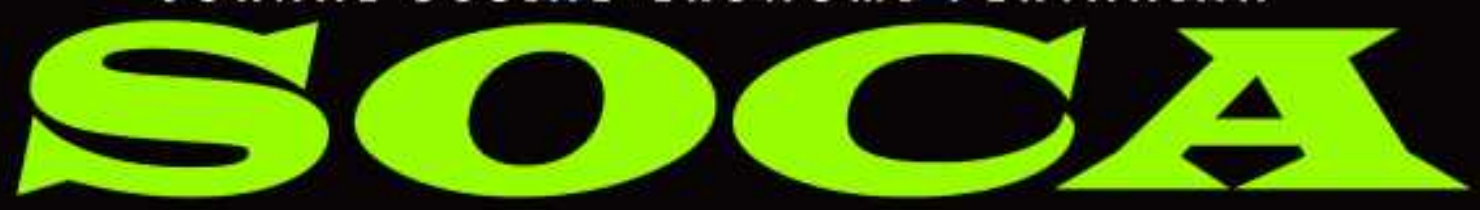

JOURNAL ON SOCIAL ECONOMICS OF AGRICULTURE

Vol.13 No.2 31 Agustus 2019

e-ISSN: 2615-6628

p-ISSN: $1411-7176$

\title{
ANALISIS FAKTOR-FAKTOR YANG MEMPENGARUHI PENDAPATAN USAHA TERNAK SAPI PERAH KELOMPOK TANI TERNAK REJEKI LUMINTU DI KELURAHAN SUMURREJO KECAMATAN GUNUNGPATI SEMARANG
}

\author{
Dita Ervina, Agus Setiadi dan Titik Ekowati \\ Program Studi Agribisnis, Fakultas Peternakan dan Pertanian, \\ Universitas Diponegoro, Tembalang, Semarang, Jawa Tengah \\ Email: dditaervina17@gmail.com \\ Hp: 081233842632
}

\begin{abstract}
ABSTRAK
Sapi perah merupakan ternak penghasil protein hewani berupa susu dan daging. Permasalahan usaha ternak sapi perah di Indonesia yaitu umumnya masih dilakukan secara tradisional dengan skala usaha kecil. Selain itu, peternak belum berorientasi ekonomi sehingga pengeluaran untuk biaya produksi tidak memperhitungkan. Tinggi rendahnya pendapatan usaha ternak sapi perah dipengarui oleh faktor-faktor ekonomi seperti jumlah kepemilikan sapi perah laktasi, jumlah produksi susu, harga jual ternak, upah tenaga kerja, harga bahan pakan tambahan erta harga jual susu. Penelitian ini bertujuan untuk menganalisis pendapatan dan menganalisis faktor-faktor yang mempengaruhi pendapatan usaha ternak sapi perah Kelompok Tani Ternak (KTT) Rejeki Lumintu di Kelurahan Sumurrejo, Kecamatan Gunungpati, Semarang. Metode Penelitian menggunakan metode sensus dan anggota kelompok tani secara keseluruhan digunakan sebagai sampel yaitu 31 responden. Penelitian dilaksanakan pada bulan NovemberDesember 2018 di Kelurahan Sumurrejo, Kecamatan Gunungpati, Semarang. Daerah penelitian ditentukan secara purposive (sengaja). Sumber data menggunakan data primer dan data sekunder. Metode analisis data yang digunakan yaitu metode kuantitatif. Analisis data menggunakan analisis regresi linier berganda dan uji beda one sample t-test. Hasil penelitian menunjukkan bahwa pendapatan bersih dari usaha tenak sapi perah berbeda secara signifikan dengan nilai lebih tinggi dari UMK Semarang 2018. Hasil analisis regresi linier berganda diperoleh persamaan $\mathrm{Y}=15,858+7,913 \mathrm{X} 1-8,085 \mathrm{X} 2+6,875 \mathrm{X} 3-2,385 \mathrm{X} 4+0,527 \mathrm{X} 5$ dengan nilai koefisien determinasi (R2) sebesar 0,863. Hasil uji F secara serempak menunjukkan variabel independen jumlah ternak laktasi terkoreksi jumlah produksi susu, harga ternak, upah tenaga kerja, harga susu dan harga pakan tambahan berpengaruh nyata terhadap variabel dependen pendapatan. Uji t secara parsial menunjukkan jumlah ternak laktasi terkoreksi jumlah produksi susu, harga ternak, upah tenaga kerja, dan harga pakan tambahan berpengaruh nyata terhadap
\end{abstract}


pendapatan, sedangkan variabel harga susu secara parsial tidak berpengaruh nyata terhadap pendapatan.

Kata Kunci: pendapatan, peternak, sapi perah

\title{
ANALYSIS OF FACTORS AFFECTING THE INCOME OF DAIRY CATTLE FARM IN KTT REJEKI LUMINTU IN SUMURREJO VILLAGE, GUNUNGPATI DISTRICT, SEMARANG CITY
}

\begin{abstract}
Dairy cattle is a type of livestock that was used to meet animal protein. The problem of dairy cattle farm in Indonesia was generally still small with a small scale of farm. farmers were not been economically oriented so they do not account the costs incurred during the production process. The high and low income of dairy cattle farm was influenced by economic factors such as the amount of lactation cattle, the amount of dairy products, the price of cattle, labor wages, the price of milk, and the price of additional feed. The study aimed to analyze income of dairy cattle farm and analyze the factors that influence the income of dairy cattle farm in livestock farmer groups (KTT) Rejeki Lumintu in Sumurrejo Village, Gunungpati District, Semarang City. This study was conducted on November-Desember 2018 in Sumurrejo Village, Gunungpati District, Semarang City, which was selected purposively. The datas collected are primary and secondary datas. The method used was census method with 31 respondents. Data analysis methods used quantitative methods. The data analyze used multiple linear regression and one sample t-test. The result of this study showed that the net income and famer's income was higher than the Semarang City Minim was Waged (UMK) in 2018. Based on the results of multiple linear regression analysis obtained multiple equations $Y=15.858+7.913 X 1-8.085 X 2+6.875 X 3-2.385 X 4$ $+0.527 X 5$ with the value of determination coefficent (R2) was 0.863 . The result of $F$ test simultaneously the independent variables which include the amount of lactation cattle corrected by the amount of dairy products, the price of cattle, labor wages, the price of milk, and the price of additional feed were very significant on the dependent variable of net income. T-test of the partial the amount of lactation cattle corrected by the amount of dairy products, the price of cattle, labor wages, and the price of additional feed were very significant on the net income, meanwhile the price of milk partially did not significantly affect to the net income.
\end{abstract}

Keyword: breeder, dairy cattle, incom

\section{PENDAHULUAN}

Sektor peternakan mempunyai potensi yang besar untuk dikembangkan karena berperan sangat penting dalam hal pemenuhan kebutuhan manusia akan pangan terutama protein hewani. Kebutuhan produk dari peternakan semakin meningkat mengingat tingginya kandungan protein, energi, vitamin

https://ojs.unud.ac.id/index.php/soca dan mineral yang dimiliki oleh produk peternakan. Kesadaran masyarakat terkait pentingnya kandungan gizi dan kesehatan khususnya protein hewani menjadikan makanan tersebut dipilih sebagai konsumsi masyarakat. Seiring dengan pertumbuhan ekonomi, peningkatan pendapatan serta pertambahan jumlah penduduk maka bertambah pula permintaan protein hewani. Permintaan protein di https://doi.org/10.24843/SOCA.2019.v13.i02.p04 
Indonesia meningkat dari tahun 2016 ke 2017 dengan rata-rata konsumsi berturut-turut 56,67 dan 62,20 gram/kapita/hari (Badan Pusat Statistik, 2017) sehingga dapat menjadi peluang usaha karena memiliki permintaan yang tinggi.

Salah satu jenis ternak yang digunakan untuk memenuhi protein hewani adalah ternak sapi. Sapi dikenal sebagai ternak yang mudah untuk di budidayakan khususnya di daerah pedesaan karena memiliki rumput dan dedaunan yang dapat dijadikan sebagai pakan ternak. Oleh karena itu, masyarakat banyak yang membudidayakan ternak sapi sebagai usaha. Sapi perah merupakan ternak penghasil protein hewani berupa susu dan daging. Susu sapi perah memiliki kandungan berbagai nutrisi yaitu protein, lemak, karbohidrat (laktosa), vitamin dan mineral. Selain itu dalam kehidupan sehari-hari kotoran dan air seni dapat dimanfaatkan sebagai pembuatan pupuk, biogas maupun kompos. Banyaknya manfaat yang dapat diperoleh dari usaha ini menjadi potensi untuk meningkatkan pendapatan.

Usaha ternak sapi perah di Indonesia umumnya masih dilakukan secara tradisional dengan skala usaha kecil. Selain itu, peternak belum berorientasi ekonomi sehingga pengeluaran untuk biaya produksi tidak memperhitungkan. Padahal biaya sangat mempengaruhi jumlah pendapatan yang akan diterima oleh peternak. Tinggi rendahnya pendapatan usaha ternak sapi perah dipengaruhi oleh faktor-faktor seperti jumlah kepemilikan sapi perah laktasi, harga jual ternak, jumlah produksi susu, upah tenaga kerja, harga susu, dan harga pakan tambahan.
Berdasarkan

penelitian terdahulu yang dilakukan oleh Santosa et al. (2013) diperoleh hasil bahwa pendapatan yang diperoleh peternak di Kecamatan Musuk Kabupaten Boyolali sebesar Rp 1.466.307/bl lebih tinggi dari UMR Boyolali yaitu Rp 960.000/bl. Sedangkan analisis regresi linier berganda menunjukkan bahwa biaya pakan, produksi susu dan umur peternakmemiliki pengaruh yang nyata terhadap pendapatan usaha ternak sapi perah.

$$
\text { Penelitian Alpian (2010) }
$$

menunjukkan hasil bahwa
pendapatan peternak sapi perah di Kecamatan Tanjungsari Kabupaten Sumedang sebesar Rp $10.602 .237,74 /$ th. Sedangkan untuk analisis regresi diperoleh hasil bahwa penjualan susu, upah tenaga kerja, biaya kesehatan hewan, harga vaselin, harga ampas tahu, harga konsentrat dan harga hijauan memiliki pengaruh yang nyata terhadap pendapatan usaha ternak sapi perah.

Penelitian Fajri et al. (2016) diperoleh hasil pendapatan skala usaha I, II, dan III berturut-turut Rp 355.729/bl/ST, Rp 398.299/bl/ST, dan Rp 376.731/bl/ST. Faktor curahan tenaga kerja dan skala usaha berpengaruh nyata terhadap pendapatan anggota KPSP Manglayang.

Penelitan Rahayu et al. (2014) menunjukkan hasil bahwa pendapatan peternak di Kecamatan Getasan Kabupaten Semarang sebesar Rp. 11.097.506/th lebih besar dari UMK Semarang yaitu 10.344.000/tahun $\quad(\mathrm{P} \leq 0,01)$. Sedangkan faktor yang mempengaruhi pendapatan usaha ternak sapi perah yaitu umur peternak, curahan waktu usaha sapi perah, pengalaman 
beternak, kontribusi pendapatan non usahatani, kontribusi pendapatan usaha tanaman pertanian dan jumlah ternak.

(2013) menunjukkan hasil bahwa keuntungan usaha ternak sapi perah rakyat di Kota Semarang dipengaruhi oleh biaya tenaga kerja, biaya obatobatan dan kepemilikan modal.

Kelompok Tani Ternak (KTT) Rejeki Lumintu merupakan kelompok tani yang berada di Dk. Kaum RT 02 RW 04 Kelurahan Sumurrejo, Kecamatan Gunungpati, Semarang. KTT ini bergerak di bidang peternakan yaitu usaha ternak sapi perah. KTT ini dibentuk pada tahun 1990 dengan jumlah anggota awal 15 orang dan saat ini menjadi 33 orang. KTT ini dibentuk berdasarkan kemauan peternak untuk membentuk kelompok serta untuk memperbaiki kondisi ekonomi. Nama Rejeki Lumintu sendiri memiliki makna yaitu Rejeki atau Rezeki dan Lumintu yang artinya Mengalir, dengan nama tesebut diharapkan dengan terbentuknya kelompok tani ini rezeki tak hentihentinya akan mengalir sehingga pendapatan dan kesejahteraan anggota meningkat. Awal kelompok ini berdiri kandang masih berada di

\section{METODE PENELITIAN}

Penelitian dilaksanakan bulan November-Desember 2018 yang berlokasi di Kelurahan Sumurrejo, Kecamatan Gunungpati, Semarang. Tempat penelitian ditentukan secara purposive dengan pertimbangan bahwa di kelurahan tersebut terdapat kelompok tani dengan usaha ternak sapi perah yang sudah berkembang karena memiliki ternak 150 ekor dengan 33 anggota aktif dan berprestasi Juara II di tingkat provinsi. rumah-rumah, kemudian berdasarkan kesepakatan anggota kandang di pindah untuk menghindari pencemaran lingkungan. Kandang pindah di lahan bengkok kelurahan Sumurrejo yang dilakukan dengan cara sewa. Luas lahan bengkok yaitu 1,5 $\mathrm{Ha}$ terdiri dari lahan hijauan untuk pakan ternak $8.000 \mathrm{~m} 2$ dan 7000 m2 untuk bangunan kandang.

\section{Permasalahan yang dihadapi} oleh KTT Rejeki Lumintu dalam menjalankan usaha ternak sapi perah adalah harga pakan yang semakin tinggi, biaya Inseminasi Buatan, biaya obat-obatan maupun upah yang diberikan kepada tenaga kerja. Untuk itu diperlukan penelitian mengenai faktor-faktor yang memiliki pengaruh terhadap pendapatan usaha ternak sapi perah agar dapat diketahui faktor apa saja yang harus ditekan dan faktor apa yang seharusnya ditambah agar diperoleh pendapatan yang tinggi.

Penelitian ini bertujuan untuk menganalisis pendapatan dan menganalisis faktor-faktor yang mempengaruhi pendapatan usaha ternak sapi perah Kelompok Tani Ternak (KTT) Rejeki Lumintu di Kelurahan Sumurrejo, Kecamatan Gunungpati, Semarang.

Dalam rangka penilaian lomba kelompok tani ternak berprestasi (komoditas sapi perah) tahun 2018. Metode penelitian menggunakan metode sensus yang dilakukan di KTT Rejeki Lumintu di Kelurahan Sumurrejo, Kecamatan Gunungpati, Semarang untuk meneliti semua sampel dalam populasi. Kerangka Penelitian dapat dilihat pada Ilustrasi 1.

Metode pengumpulan data dilakukan dengan mengumpulkan data primer dan juga data sekunder. 
Data primer diperoleh dari hasil observasi serta wawancara dengan peternak sapi perah menggunakan panduan kuesioner yang sudah disiapkan sebelumnya. Data primer yang dikumpulkan berupa identitas responden, aset yang dimiliki dalam usaha ternak, biaya produksi yang dikeluarkan, jenis produk yang ditawarkan, jumlah produksi dan harga untuk masing-masing produk dari usaha yang dijalankan. Data sekunder diperoleh dari institusi serta sumber pustaka-pustaka terkait dengan materi penelitian. Data sekunder yang dikumpulkan berupa keadaan geografis dan demografi Kelurahan Sumurrejo, Kecamatan Gunungpati, Semarang. Metode analisis data yang digunakan yaitu metode kuantitatif. Data diolah dengan Microsoft Excel dan SPSS 23. Analisis pendapatan menggunakan rumus yaitu (Ekowati et al., 2014):

Keterangan:

$$
\begin{aligned}
& \mathrm{PB}=\mathrm{PK}-\mathrm{BU} \\
& \mathrm{PK}=\mathrm{Y} \times \mathrm{Py} \\
& \mathrm{BU}=\mathrm{BAL}+\mathrm{UTKK}
\end{aligned}
$$

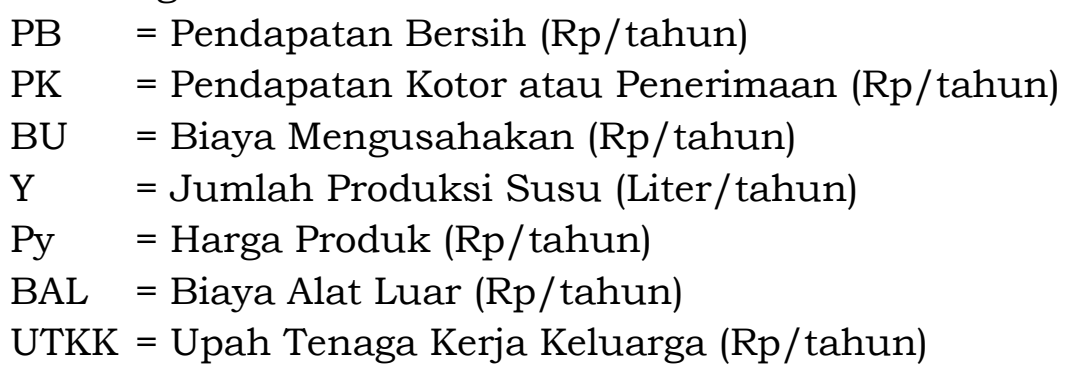

Rata-rata pendapatan bersih peternak sapi perah anggota KTT Rejeki Lumintu di Kelurahan Sumurrrejo, Kecamatan Gunungpati, Semarang dibandingkan dengan UMK Semarang yang dianalisis menggunakan uji beda One sample $t$ test.

\section{Hipotesis}

HO $: \mu-\mu 0 \neq$ Rp. 2.310.0877,50 $\rightarrow$ pendapatan bersih peternak sapi perah KTT Rejeki Lumintu di Keluahan Sumurrejo, Kecamatan Gunungpati,

$$
\mathrm{Y}=\mathrm{a}+\mathrm{b} 1 \mathrm{X} 1+\mathrm{b} 2 \mathrm{X} 2+\mathrm{b} 3 \mathrm{X} 3+\mathrm{b} 4 \mathrm{X} 4+\mathrm{b} 5 \mathrm{X} 5+\mathrm{e}
$$

Keterangan:

$\mathrm{Y} \quad=$ Pendapatan $(\mathrm{Rp} /$ tahun$)$

a $\quad$ Koefisien konstanta

$\mathrm{b}=$ Koefisien regresi

$\mathrm{X} 1=$ Jumlah kepemilikan sapi laktasi (ekor)

$\mathrm{X} 2=$ Harga jual ternak (Rp/ekor)

$\mathrm{X} 3=$ Jumlah produksi susu (liter/tahun)
Semarang tidak berbeda dengan UMK Semarang.

H1 $: \mu-\mu 0=$ Rp. 2.310.0877,50 $\rightarrow$ pendapatan bersih peternak sapi perah KTT Rejeki Lumintu di Keluahan Sumurrejo, Kecamatan Gunungpati, Semarang berbeda dengan UMK Semarang.

Analisis faktor-faktor yang mempengaruhi usaha ternak sapi perah di analisis dengan regresi linier berganda dengan model regresi: 

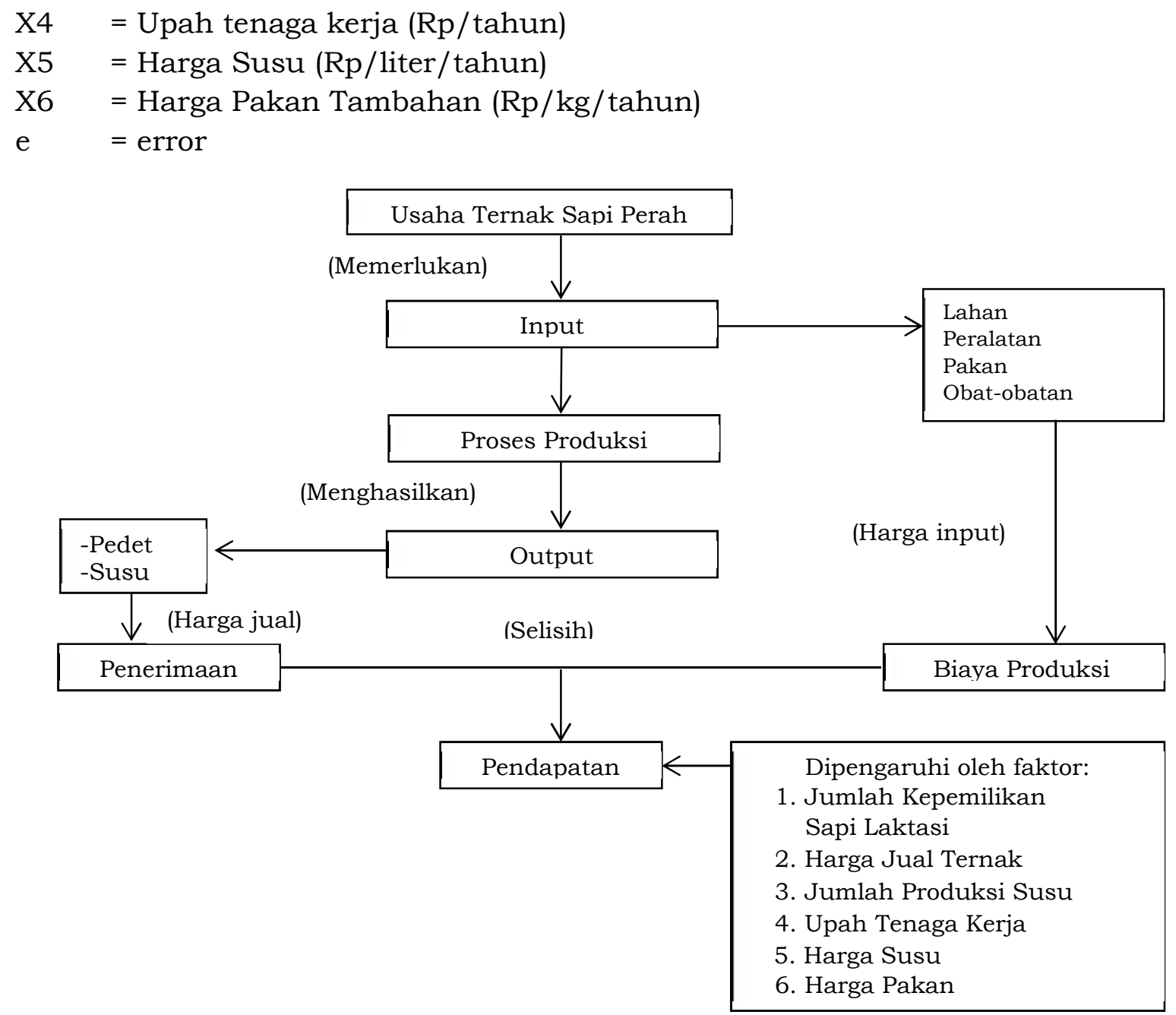

Gambar 1. Kerangka Penelitian

Uji hipotesis digunakan untuk mengetahui signifikansi dari koefisien regresi. Uji F, Uji t, dan uji koefisien determinasi (R2) termasuk dalam uji hipotesis. Uji $\mathrm{t}$ digunakan untuk mengetahui pengaruh satu variabel independen secara individual terhadap variabel terikat (Zaenuddin, 2015). Jika nilai sig $<0,05$ atau $t$ hitung $>t$ tabel maka secara parsial variabel independen berpengaruh terhadap variabel dependen (Kuncoro, 2009).

\section{Hipotesis Statistik:}

1. H0: bX1, X2, X3, X4, X5, X6, Y = 0

Jumlah kepemilikan ternak laktasi, harga jual ternak, jumlah produksi susu, upah tenaga kerja, harga susu, dan harga pakan tambahan tidak mempengaruhi pendapatan petani

2. H1: $\mathrm{bX} 1, \mathrm{X} 2, \mathrm{X} 3, \mathrm{X} 4, \mathrm{X} 5, \mathrm{X} 6, \mathrm{Y} \neq 0$

Jumlah kepemilikan ternak laktasi, harga jual ternak, jumlah produksi susu, upah tenaga kerja, harga susu, dan harga pakan tambahan mempengaruhi pendapatan petani

Uji $F$ atau uji serempak digunakan untuk melihat apakah seluruh variabel independen memiliki pengaruh secara serempak terhadap variabel dependen (Zaenuddin, 2015). Jika nilai signifikansi $<0,05$ atau nilai $\mathrm{F}$ hitung $>\mathrm{F}$ tabel maka variabel independen secara serempak signifikan berpengaruh terhadap variabel dependen (Kuncoro, 2009). 


\section{Hipotesis Statistik:}

1. H0: bX1, $\mathrm{X} 2, \mathrm{X} 3, \mathrm{X} 4, \mathrm{X} 5, \mathrm{X} 6, \mathrm{Y}=0$ Jumlah kepemilikan ternak laktasi, harga jual ternak, jumlah produksi susu, upah tenaga kerja, harga susu, dan harga pakan tambahan tidak mempengaruhi pendapatan petani

2. $\mathrm{H} 1 \mathrm{bX} 1, \mathrm{X} 2, \mathrm{X} 3, \mathrm{X} 4, \mathrm{X} 5, \mathrm{X} 6, \mathrm{Y} \neq 0$

Jumlah kepemilikan ternak laktasi, harga jual ternak, jumlah produksi susu, upah tenaga kerja, harga susu, dan harga pakan tambahan mempengaruhi pendapatan petani

Uji koefisien determinasi (R2) digunakan untuk mengukur seberapa besar variabel independen dapat menjelaskan variabel dependen dapat dilakukan dengan uji koefisien determinasi. (Zaenuddin, 2015).

Asumsi klasik merupakan uji yang digunakan untuk memenuhi persyaratan statistik sebelum melakukan analisis regresi linear berganda. Uji normalitas, uji heteroskedastisitas, uji multikolinearitas dan uji autokorelasi termasuk dalam uji asumsi klasik. Identitas responden meliputi jenis kelamin, pendidikan, umur dan lama beternak.

Uji hipotesis digunakan untuk mengetahui signifikansi dari koefisien regresi. Uji F, Uji t, dan uji koefisien determinasi $\left(\mathrm{R}^{2}\right)$ termasuk dalam uji hipotesis. Uji $t$ digunakan untuk mengetahui pengaruh satu variabel independen secara individual terhadap variabel terikat (Zaenuddin, 2015). Jika nilai sig $<0,05$ atau $\mathrm{t}$ hitung $>\mathrm{t}$ tabel maka secara parsial variabel independen berpengaruh terhadap variabel dependen (Kuncoro, 2009).

\section{Hipotesis Statistik:}

1. $\mathrm{H}_{0}: \mathrm{bX}_{1}, \mathrm{X}_{2}, \mathrm{X}_{3}, \mathrm{X}_{4}, \mathrm{X}_{5}, \mathrm{X}_{6}, \mathrm{Y}=0$
Jumlah kepemilikan ternak laktasi, harga jual ternak, jumlah produksi susu, upah tenaga kerja, harga susu, dan harga pakan tambahan tidak mempengaruhi pendapatan petani

2. $\mathrm{H}_{1}: \mathrm{bX}_{1}, \mathrm{X}_{2}, \mathrm{X}_{3}, \mathrm{X}_{4}, \mathrm{X}_{5}, \mathrm{X}_{6}, \mathrm{Y} \neq 0$

Jumlah kepemilikan ternak laktasi, harga jual ternak, jumlah produksi susu, upah tenaga kerja, harga susu, dan harga pakan tambahan mempengaruhi pendapatan petani

Uji $F$ atau uji serempak digunakan untuk melihat apakah seluruh variabel independen memiliki pengaruh secara serempak terhadap variabel dependen (Zaenuddin, 2015). Jika nilai signifikansi $<0,05$ atau nilai $\mathrm{F}$ hitung $>\mathrm{F}$ tabel maka variabel independen secara serempak signifikan berpengaruh terhadap variabel dependen (Kuncoro, 2009).

\section{Hipotesis Statistik:}

1. $\mathrm{H}_{0}: \mathrm{bX}_{1}, \mathrm{X}_{2}, \mathrm{X}_{3}, \mathrm{X}_{4}, \mathrm{X}_{5}, \mathrm{X}_{6}, \mathrm{Y}=0$

Jumlah kepemilikan ternak laktasi, harga jual ternak, jumlah produksi susu, upah tenaga kerja, harga susu, dan harga pakan tambahan tidak mempengaruhi pendapatan petani

2. $\mathrm{H}_{1}: \mathrm{bX} \mathrm{X}_{1}, \mathrm{X}_{2}, \mathrm{X}_{3}, \mathrm{X}_{4}, \mathrm{X}_{5}, \mathrm{X}_{6}, \mathrm{Y} \neq 0$

Jumlah kepemilikan ternak laktasi, harga jual ternak, jumlah produksi susu, upah tenaga kerja, harga susu, dan harga pakan tambahan mempengaruhi pendapatan petani

Uji koefisien determinasi $\left(\mathrm{R}^{2}\right)$ digunakan untuk mengukur seberapa besar variabel independen dapat menjelaskan variabel dependen dapat dilakukan dengan uji koefisien determinasi. (Zaenuddin, 2015). Asumsi klasik merupakan uji yang digunakan untuk memenuhi persyaratan statistik sebelum melakukan analisis regresi linear berganda. Uji normalitas, uji 
heteroskedastisitas, uji multikolinearitas dan uji autokorelasi termasuk dalam uji asumsi klasik.
Identitas responden meliputi jenis kelamin, pendidikan, umur dan lama beternak.

\section{HASIL DAN PEMBAHASAN}

Tabel 1. Jumlah dan Persentase Berdasarkan Identitas Responden

\begin{tabular}{|c|c|c|c|}
\hline No & Identitas Responden & Jumlah & Persentase \\
\hline & & ---jiwa--- & ---\%--- \\
\hline \multirow[t]{4}{*}{1.} & Jenis Kelamin & & \\
\hline & Laki-laki & 31 & 100,000 \\
\hline & Perempuan & 0 & 0,000 \\
\hline & Jumlah & 31 & 100,000 \\
\hline \multirow[t]{5}{*}{2.} & Pendidikan & & \\
\hline & $\mathrm{SD}$ & 15 & 48,387 \\
\hline & SMP & 9 & 29,032 \\
\hline & SMA & 7 & 22,581 \\
\hline & Jumlah & 31 & 100,000 \\
\hline \multirow[t]{7}{*}{3.} & Umur (Tahun) & & \\
\hline & $<34$ & 3 & 9,677 \\
\hline & $35-44$ & 7 & 22,581 \\
\hline & $45-54$ & 5 & 16,129 \\
\hline & $55-64$ & 11 & 35,484 \\
\hline & $>65$ & 5 & 16,129 \\
\hline & Jumlah & 31 & 100,000 \\
\hline \multirow[t]{5}{*}{4.} & $\begin{array}{l}\text { Lama Beternak } \\
\text { (Tahun) }\end{array}$ & & \\
\hline & $<5$ & 4 & 12,903 \\
\hline & $6-15$ & 12 & 38,710 \\
\hline & $>16$ & 15 & 48,387 \\
\hline & Jumlah & 31 & 100,000 \\
\hline
\end{tabular}

Sumber: Data primer penelitian yang telah diolah, 2019.

Tabel 1. menunjukkan bahwa dari keseluruhan responden 31 orang berjenis kelamin laki-laki atau 100\% adalah laki-laki. Hal tersebut menunjukkan bahwa usaha ternak lebih banyak dilakukan oleh laki-laki daripada perempuan. Tenaga kerja perempuan hanya bersifat membantu agar pekerjaan lebih ringan dan cepat terselesaikan. Untuk itu dalam kegiatan usaha ternak sapi perah yang paling banyak berperan adalah lakilaki. Hal tersebut sesuai pendapat dari Sari et al. (2009) bahwa mayoritas peternak berjenis kelamin laki-laki karena pekerjaan ini menggunakan kekuatan fisik yang lebih. Namun tidak menutup kemungkinan jika pekerjaan ini dilkukan juga oleh wanita. Welerubun et al. (2016) menyatakan bahwa pada umumnya peternak laki-laki mendominasi usaha ternak karena laki-laki mempunyai tenaga dan kemampuan yang besar dalam mengelola usahanya sedangkan perempuan hanya berperan sebagai pengawas usaha manakala suaminya tidak berada pada saat harus mengurusi ternak-ternaknya.

Pendidikan responden dapat diketahui bahwa dari keseluruhan responden menunjukkan hasil tingkat pendidikan akhir responden paling banyak yaitu pada tingkat Sekolah Dasar (SD) sebanyak 15 orang dengan persentase $48,387 \%$, artinya 


\begin{abstract}
rata-rata pendidikan responden tergolong rendah. Rendahnya pendidikan berhubungan dengan rendahnya pengetahuan atau pola pikir peternak, sehingga akan sulit menerima inovasi baru untuk menjalankan usaha ternaknya. Hal tersebut sesuai pendapat Luanmase et al. (2011) bahwa tingkat pendidikan mencerminkan seseorang dapat menerima inovasi atau tidak. Semakin tinggi pendidikan maka akan semakin mudah seseorang dalam menerima informasi baru terkait dengan usaha ternak.
\end{abstract}

Umur responden menunjukkan
hasil bahwa dari keseluruhan responden, umur paling banyak pada kisaran 55-64 tahun dengan jumlah 11 orang dan persentase 35,484\%, artinya umur peternak sapi perah KTT Rejeki lumintu tergolong umur produktif. Otampi et al. (2017) menyatakan bahwa umur produktif yaitu pada kisaran umur 15-64 tahun sedangkan umur non produktif yaitu pada umur $\geq 65$ tahun. Umur akan menentukan produktif tidaknya seseorang dalam melakukan suatu pekerjaan. Hal tersebut sesuai pendapat Lestariningsih et al. (2006) bahwa semakin tua umur peternak maka kemampuan peternak untuk melakukan pekerjaan akan semakin menurun.

Pengalaman responden menunjukkan hasil bahwa dari keseluruhan responden, pengalaman beternak responden paling banyak yaitu > 16 tahun sebanyak 15 orang dengan persentase 48,387\%. Hal ini menunjukkan bahwa rata-rata pengalaman beternak responden cukup lama, karena pada umumnya usaha peternakan merupakan usaha turun-temurun. Hal tersebut sesuai dengan pendapat dari Setianti et al. (2015) yang menyatakan bahwa sebagian besar pengalaman beternak diperoleh peternak secara turun- temurun dari orang tuanya. Pengalaman beternak mempengaruhi keterampilan peternak dalam mengatasi masalah dalam usaha ternak yang dijalankannya, semakin lama pengalaman beternak maka keterampilan peternak dalam menjalankan usahanya akan semakin baik.

\section{Pendapatan Peternak Sapi Perah}

Rata-rata pendapatan bersih KTT Rejeki Lumintu adalah sebesar Rp $28.153 .947 /$ th. Pendapatan tersebut diperoleh dari penerimaan dikurangi dengan biaya mengusahakan. Ratarata penerimaan usaha sebesar $\mathrm{Rp}$ $57.853 .143 /$ th. Penerimaan tersebut diperoleh dari rata-rata penjualan susu yaitu Rp 42.672.49/th, penjualan ternak $\mathrm{Rp} 12.722 .581 /$ th dan penjualan feses sebesar $\mathrm{Rp}$ $2.458 .065 /$ th. Rata-rata biaya yang dikeluarkan sebesar Rp 29.699.196/th. Hal tersebut sesuai pendapat Ekowati et al. (2014) yang menyatakan bahwa jika pendapatan kotor dikurangi dengan biaya mengusahakan maka diperoleh pendapatan bersih.

Berdasarkan uji one sample ttest diperoleh nilai signifikansi $0,000<0,05$ sehingga $\mathrm{HO}$ ditolak dan $\mathrm{H} 1$ diterima. Hal tersebut sesuai dengan pendapat Santoso (2012) yang menyatakan bahwa jika nilai probabilitas $>0,05$ maka H0 diterima dan jika nilai probabilitas $<0,05$ maka HO ditolak. Hal tersebut menunjukkan bahwa terdapat perbedaan antara pendapatan usaha ternak dengan UMK Kota Semarang 2018 yaitu Rp $27.721 .050 /$ th.

\section{Analisis Regresi Linier Berganda}

Persamaan hasil uji analisis regresi linier berganda:

$$
\begin{gathered}
\mathrm{Y}=15,858+7,913 \mathrm{X} 1-8,085 \mathrm{X} 2+ \\
6,875 \mathrm{X} 3-2,385 \mathrm{X} 4+0,527 \mathrm{X} 5 \\
\text { Uji F menunjukkan nilai } \\
\text { signifikansi } 0,00<0,05 \text { yang artinya }
\end{gathered}
$$


variabel independen harga ternak, upah tenaga kerja, harga susu, harga pakan tambahan, jumlah sapi laktasi dan jumlah produksi susu secara serempak berpengaruh terhadap variabel dependen pendapatan usaha ternak KTT Rejeki Lumintu. Hal tersebut sesuai dengan pendapat Zaenuddin (2015) yang menyatakan bahwa untuk melihat apakah seluruh variabel independen memiliki pengaruh secara serempak terhadap variabel dependen dapat dilakukan dengan uji F. Kuncoro (2009) berpendapat jika nilai signifikansi < 0,05 atau nilai $\mathrm{F}$ hitung $>\mathrm{F}$ tabel maka variabel independen secara serempak signifikan memiliki pengaruh terhadap variabel variabel dependen.

Tabel 2. Hasil Uji Regresi Linier Berganda

\begin{tabular}{lccc}
\hline \hline No & Variabel & Koefisien Regresi & Sig. \\
\hline 1 & Konstan & 15,858 &, 000 \\
2 & Harga Jual Ternak $\left(\mathrm{X}_{1}\right)$ & $7,913 \mathrm{E}-8$ &, 000 \\
3 & Upah Tenaga Kerja $\left(\mathrm{X}_{2}\right)$ & $-8,085 \mathrm{E}-8$ &, 009 \\
4 & Harga Susu $\left(\mathrm{X}_{3}\right)$ & $6,875 \mathrm{E}-6$ &, 964 \\
5 & Harga Pakan Tambahan $\left(\mathrm{X}_{4}\right)$ & $-2,385 \mathrm{E}-6$ &, 024 \\
6 & Jumlah Sapi Laktasi &, 527 &, 000 \\
& Terkoreksi Jumlah Produksi & \\
$\quad$ Susu $\left(\mathrm{X}_{5}\right)$ & \\
\hline \multicolumn{5}{c}{$=0,000$} \\
\hline
\end{tabular}

Sumber: Data primer penelitian yang telah diolah, 2019.

Uji t menunjukkan bahwa harga jual ternak (X1) mempunyai pengaruh yang signifikan terhadap pendapatan anggota KTT Rejeki Lumintu dengan nilai signifikansi $0,000<0,05$. Variabel harga jual ternak berpengaruh terhadap pendapatan karena penerimaan berasal dari penjualan ternak, penjualan susu dan penjualan kotoran. Penjualan ternak akan menutupi biaya produksi yang telah dikeluarkan oleh peternak. Hal tersebut sesuai pendapat Puspitasari (2016) bahwa harga jual ternak berpengaruh terhadap pendapatan peternak. Koefisien regresi variabel harga jual ternak sebesar 7,913E-8. Setiap kenaikan 1 satuan harga jual ternak maka pendapatan akan naik sebesar 7,913E-8, artinya semakin banyak sapi yang dijual maka pendapatan yang diperoleh akan semakin banyak pula. Hal tersebut sesuai pendapat Welerubun et al. (2016) bahwa peningkatan harga jual ternak mengakibatkan penerimaan peternak menjadi meningkat dan pendapatan yang diterima akan lebih besar.

Upah tenaga kerja (X2) memiliki pengaruh signifikan terhadap pendapatan anggota KTT Rejeki Lumintu dengan nilai signifikansi sebesar $0,009<0,05$. Variabel upah tenaga kerja berpengaruh karena banyaknya upah yang diberikan akan menambah biaya produksi yang nantinya akan mempengaruhi pendapatan. Peternak KTT Rejeki Lumintu menggunakan tenaga kerja keluarga yaitu laki laki, istri dan anaknya untuk melakukan kegiatan beternak. Tenaga kerja keluarga merupakan biaya yang diperhitungkan berdasarkan upah tenaga kerja luar. Selain tenaga kerja 
dalam keluarga, ada juga peternak yang mempekerjakan tenaga kerja luar keluarga. Banyaknya jumlah tenaga kerja yang digunakan akan mengakibatkan pengeluaran biaya produksi yang lebih besar sehingga akan berpengaruh terhadap pendapatan. Hal tersebut sesuai pendapat Alpian (2010) bahwa upah tenaga kerja memiliki pengaruh nyata terhadap pendapatan, jika upah tenaga kerja naik ataupun turun akan berpengaruh terhadap pendapatan. Koefisien regresi variabel upah tenaga kerja sebesar -8,085E-8. Setiap kenaikan 1 satuan maka pendapatan akan turun sebesar 8,085E-8, artinya semakin banyak upah tenaga kerja maka pendapatan akan menurun. Hal tersebut sesuai dengan pendapat Welerubun et al. (2016) yang menyatakan bahwa penambahan tenaga kerja akan menurunkan pendapatan peternak.

Harga pakan tambahan (X4) mempunyai pengaruh yang signifikan terhadap pendapatan anggota KTT Rejeki Lumintu dengan nilai signifikansi $0,024<0,05$. Variabel harga pakan tambahan berpengaruh terhadap pendapatan karena harga pakan tambahan merupakan biaya yang paling besar yang dikeluarkan peternak dalam biaya produksi sehingga akan mempengaruhi pendapatan. Hal tersebut sesuai pendapat Setiawan et al. (2014) bahwa meningkatnya harga pakan menyebabkan biaya produksi usaha ternak meningkat pula. Harga pakan yang tinggi sangat berpengaruh terhadap tingkat pendapatan yang diperoleh peternak, selain itu pendapatan peternak tidak akan maksimal dan peternak akan sulit untuk melakukan pengembangan usaha ternaknya. Koefisien regresi variabel harga pakan tambahan sebesar -2,385E-6. Setiap kenaikan 1 satuan harga pakan maka pendapatan akan turun sebesar 2,385E-6, artinya semakin tinggi harga pakan maka pendapatan akan semakin menurun. Hal tersebut sesuai pendapat Otampi et al. (2017) yaitu apabila harga pakan naik maka pendapatan akan menurun.

Jumlah sapi laktasi terkoreksi jumlah produksi susu (X5) mempunyai pengaruh yang signifikan terhadap pendapatan anggota KTT Rejeki Lumintu dengan nilai signifikansi $0,000<0,05$. Jumlah sapi laktasi terkoreksi jumlah produksi susu berpengaruh terhadap pendapatan karena jika kepemilikan sapi laktasi banyak maka otomatis produksi susu yang dihasilkan juga banyak dan susu yang dijual akan semakin banyak sehingga akan mempengaruhi penerimaan dan pendapatan. Hal tersebut sesuai pendapat Welerubun et al. (2016) bahwa kepemilikan ternak memiliki pengaruh sangat nyata terhadap pendapatan peternak. Santosa et al. (2013) menyatakan bahwa jumlah produksi susu mempunyai pengaruh nyata terhadap pendapatan usaha ternak sapi perah. Koefisien regresi variabel jumlah sapi laktasi terkoreksi jumlah produksi susu sebesar 0,527. Setiap kenaikan 1 satuan jumlah sapi maupun jumlah produksi susu maka pendapatan akan naik sebesar 0,527 artinya semakin banyak sapi laktasi yang dipelihara dan semakin banyak produksi susu yang diperoleh maka pendapatan usaha ternak sapi perah akan naik pula. Hal tersebut sesuai pendapat Siregar (1995) bahwa semakin banyak kepemilikan ternak maka jumlah produksi susu juga akan mengikuti. Semakin banyak kepemilikan ternak maka pendapatannya juga semakin bertambah besar.

Harga Susu (X3) tidak berpengaruh signifikan terhadap pendapatan anggota KTT Rejeki 
Lumintu dengan nilai signifikansi 0,964>0,05 dan koefisien regresi sebesar 6,875E-6. Setiap kenaikan 1 satuan harga susu maka pendapatan akan naik sebesar 6,875E-6, artinya semakin tinggi harga susu maka pendapatan usaha ternak sapi perah akan meningkat pula. Harga susu tidak berpengaruh karena harga susu di tingkat peternak masih tergolong rendah yaitu berkisar antara $\mathrm{Rp}$ 4.500-6.000/liter sedangkan harga susu pada tingkat konsumen $\mathrm{Rp}$ 10.347/liter (Kementrian Pertanian, 2016). Selain itu harga di tingkat peternak sudah ditentukan oleh pengepul. Nisa et al. (2012) menyatakan bahwa harga susu di tingkat peternak relatif sangat rendah, sedangkan harga konsentrat terus meningkat. Hal ini mengakibatkan peternak mendapat keuntungan yang sedikit.

Uji Koefisien Determinasi (R2) dengan nilai Adjusted $\mathrm{R}$ Square sebesar 0,863, artinya variabel dependen yaitu pendapatan peternak KTT Rejeki Lumintu sebesar 86,3\% dipengaruhi atau dapat dijelaskan oleh variabel independen harga ternak, upah tenaga kerja, harga susu, harga pakan tambahan, jumlah sapi laktasi dan jumlah produksi susu, sedangkan 13,7\% sisanya dijelaskan oleh variabel lain yang tidak diteliti. Hal tersebut sesuai dengan pendapat Zaenuddin (2015) yang menyatakan bahwa untuk mengukur seberapa besar variabel independen dapat menjelaskan variabel dependen dapat dilakukan dengan uji koefisien determinasi.

Berdasarkan hasil uji normalitas menggunakan Kolmogorov-Smirnov dapat diketahui bahwa data berdistribusi normal karena nilai Asymp. Sig. (2-tailed) 0,200 yang mana nilainya $>0,05$. Uji Multikolinearitas menunjukkan bahwa tidak ada variabel bebas yang memiliki nilai tolerance kurang dari 0,1 yang berarti tidak terjadi multikolinearitas. Uji Autokorelasi menunjukkan bahwa nilai durbin watson sebesar 2.054 . sampel (n) berjumlah 31 dan jumlah variabel bebas $5(\mathrm{k})$, sehingga berdasarkan tabel DW nilai dL dengan derajat kepercayaan 5\% yaitu 1.0904 dan du sebesar 1.8252. Nilai DW yaitu $\mathrm{dU}<\mathrm{DW}<4-\mathrm{dU}$ $(1.8252<2.054<2.1748)$ artinya tidak terjadi autokorelasi. Uji Heterokedastisitas menunjukkan hasil bahwa grafik scatterplot tidak membentuk pola yang artinya tidak terjadi heterokedastisitas.

\section{KESIMPULAN DAN SARAN}

\section{Kesimpulan}

Berdasarkan hasil penelitian tentang analisis faktor-faktor yang mempengaruhi pendapatan usaha ternak sapi perah KTT Rejeki Lumintu di Kelurahan Sumurrejo Kecamatan Gunungpati Semarang, dapat disimpulkan pendapatan usaha ternak sapi perah KTT Rejeki Lumintu sebesar Rp 872.772.364/tahun. Variabel harga jual ternak, upah tenaga kerja, harga pakan tambahan, jumlah sapi laktasi terkoreksi jumlah produksi susu mempunyai pengaruh yang nyata terhadap pendapatan usaha ternak sapi perah KTT Rejeki Lumintu, sedangkan variabel harga susu tidak mempunyai pengaruh nyata terhadap pendapatan usaha terak sapi perah KTT Rejeki Lumintu.

\section{Saran}

Sebaiknya variabel upah tenaga kerja dan harga pakan tambahan penggunaannya tidak ditambah lagi karena berpengaruh nyata dan memiliki koefisien regresi negatif sehingga akan menurunkan pendapaan peternak, sedangkan harga susu dapat ditambahkan lagi penggunaannya karena memiliki 
koefisien regresi positif sehingga pendapatan peternak dapat meningkat. Variabel harga jual ternak, jumlah sapi laktasi dan jumlah produksi susu dapat dipertahankan atau ditambah lagi penggunaannya karena berpengaruh secara nyata dan memiliki koefisien regresi positif sehingga akan meningkatkan pendapatan peternak.

\section{DAFTAR PUSTAKA}

Alpian, A. 2010. Faktor-faktor yang mempengaruhi produktivitas susu dan pendapatan peternak sapi perah di Kecamatan Tanjungsari Kabupaten Sumedang. IPB, Bogor (Skripsi Sarjana Ekonomi).

Badan Pusat Statistik. 2017. Konsumsi Kalori dan Protein Penduduk Indonesia dan Provinsi, Maret 2017. BPS, Jakarta.

Ekowati, T., D. Sumarjono, H. Setiyawan, dan E. Prasetyo. 2014. Buku Ajar Usahatani. UNDIP Press, Semarang.

Fajri, I. N., Taslim, dan Hermawan. 2016. Pengaruh skala usaha sapi perah dan curahan tenaga kerja terhadap pengaruh skala usaha sapi perah dan curahan tenaga kerja terhadap pendapatan peternak. Students E-Journal. 6(2): 1-14.

Kementrian Pertanian. 2016. Outlook Susu Komoditas Peternakan Subsektor Peternakan. Pusdatin Kementan, Jakarta.

Kuncoro, M. 2009. Metode Riset untuk Bisnis dan Ekonomi. Erlangga, Jakarta.

Lestariningsih, M., Basuki, dan Y. Endang. 2006. Peranserta wanita peternak sapi perah dalam meningkatkan taraf hidup keluarga. J. EKUITAS. 2(1): 121141.

Luanmase, C. M., S. Nurtini, dan F. T. Haryadi. 2011. Analisis motivasi beternak sapi potong bagi peternak lokal dan transmigran serta pengaruhnya terhadap pendapatan di Kecamatan Kairatu, Kabupaten Seram Bagian Barat. Buletin Peternakan. 35(2): 113-123.

Nisa, H. I., S. I. Santoso, dan Mukson. 2012. Analisis profitabilitas usaha ternak sapi perah anggota KUD di Kabupaten Semarang. Animal Agricultural Journal. 1(1): 319337.

Otampi, R. S., F. H. Elly, M. A. Manese, dan G. D. Lenzun. 2017. Pengaruh harga pakan dan upah tenaga kerja terhadap usha ternak sapi potong petani peternak di Desa Wineru Kecamatan Likupang Timur Minahasa Utara. J. Zootek. 37(2): 483-495.

Puspitasari, M. S. 2016. Faktor-faktor yang mempengaruhi pendapatan peternak sapi bali di Desa Sumber Rejo Kecamaran Megang Sakti Kabupaten Musi Rawas. J. Societa. 5(1): 32-36.

Rahayu, R. S., W. Roessali, A. Setiadi, dan Mukson. 2014. Kontribusi usaha sapi perah terhadap pendapatan keluarga peternak Di Kecamatan Getasan Kabupaten Semarang. J. Agriekonomika. 3(1): 45-54.

Riyanto, A., dan P. B. Santosa. 2013. Analisis keuntungan dan skala usaha peternakan sapi perah rakyat di Kota Semarang. Diponegoro Journal Of Economics. 2(1): 1-8.

Santosa, S. I., A. Setiadi, dan R. Wulandari. 2013. Analisis potensi 
pengembangan usaha peternakan sapi perah menggunakan paradigma agribisnis di Kecamatan Musuk Kabupaten Boyolali. Buletin Peternakan. 37(2): 125-135.

Sari, A. I., S. H. Purnomo, dan E. T. Rahayu. 2009. Sistem pembagian kerja, akses dan kontrol terhadap sumber daya ekonomi dalam keluarga peternak rakyat sapi potong di Kabupaten Grobogan. J. Sains Peternakan. 7(1): 36-44.

Setianti, C., T. Ekowati, dan A. Setiadi. 2015. Efisiensi ekonomi usaha sapi perah di Kawasan Usaha Peternakan (KUNAK) Kecamatan Pamijahan Kabupaten Bogor. J. AGROMEDIA. 33(2): 3545.

Setiawan, H. M., B. Hartono, dan H. D. Utami. 2014. Konstribusi Pendapatan Usahaternak Sapi Potong terhadap Pendapatan
Rumahtangga Peternak (Studi Kasus di Desa Sukolilo Kecamatan Jabung Kabupaten Malang). Universitas Brawijaya, Malang. (Skripsi Sarjana Peternakan).

Siregar, S. 1995. Sapi Perah: Jenis, Teknik Pemeliharaan dan Analisis Usaha. Penebar Swadaya, Jakarta.

Suratiyah, K. 2006. Ilmu Usahatani. Penebar Swadaya, Jakarta.

Welerubun, I. N., T. Ekowati, dan A. Setiadi. 2016. Faktor-faktor yang mempengaruhi pendapatan peternak domba kisar di Pulau Kisar Kabupaten Maluku Barat Daya. J. AGROMEDIA. 34(2): 5464.

Zaenuddin, Z. 2015. Isu, Problematika, Dinamika Perekonomian dan Kebijakan Publik. Deepublish, Jakarta. 